\title{
A háború hatása az enyhítő és súlyosító körülmények megítélésére a vagyon elleni büncselekmények kapcsán - különös tekintettel a Debreceni Ítélőtábla gyakorlatára
}

Jelen tanulmányban elsősorban azt a kérdéskört próbálom körüljárni, hogy az enyhítő és súlyosító körülmények megítélésére a háború miként hatott, azaz, hogy a háborúból és a korszak sajátosságaiból adódóan melyek azok a körülmények, amelyek a bírákra hatva a büntetéskiszabásban megjelentek, mint enyhítő és súlyosító körülmények, és ez által milyen eltérések mutatkoztak a büntetéskiszabás törvényi szabályozása és a gyakorlat között.

A kutatás hátterét az 1878. évi V. törvény, ${ }^{1}$ a magyar büntetőtörvénykönyv büntettekről és vétségekről vagyon elleni büncselekményekre vonatkozó része adta, e rendelkezésekkel összhangban vizsgáltam az általános részben szabályozott enyhítő és súlyosító körülmények érvényesülését. A kutatás időbeli korlátja 1920 és 1925 közé tehető, mely időszak büntető-igazságszolgáltatás szempontjából sok érdekességet tartalmaz. Az kétségtelen tény, hogy a háborúnak hatása van a kriminalitásra, ez azonban nem csak a háború alatt, hanem a véget érő első világháború után is jelentősen éreztette hatását, nyilvánvaló tehát, hogy a bünelkövetők megítélésénél is jelentős hatással bírt. Kiinduló időpontnak ezért is választottam 1920-at, valamint azért is, mert a világháború után két évvel állt helyre az alkotmányosság, így az igazságszolgáltatási rendszer már valamelyest stabilizálódni tudott. 1925-ig pedig azért korlátoltam le a kutatás időszakát, mert az erre az időszakra jellemző megnövekedett kriminalitásból adódóan a vagyon elleni büncselekmények jelentős száma miatt, alapos vizsgálódásra csak az említett öt év vonatkozásában nyílt lehetőségem.

A tanulmányomat a témához kapcsolódó szakirodalom alapos feldolgozására és a megjelölt időszakban a törvényszékek által hozott vagyon elleni büncselekményekre vonatkozó ítéletekre, és másodfokon, a Debreceni Ítélőtábla ítéleteire alapoztam, ezért elsősorban a Magyar Nemzeti Levéltár Hajdú Bihar Megyei Levéltárának VII. 2/b. fondjába tartozó 65 doboznyi levéltári forrással dolgoztam. Összesen 404 vonatkozó esetet találtam, ezekből vontam le következtetéseket a feltett kérdéshez kapcsolódóan.

Úgy vélem, a büntetéskiszabás a büntetőjogon belül különös jelentőséggel bír az elkövetőre és a társadalomra nézve, ugyanis e ponton tud kapcsolódni a jog elvont

\footnotetext{
${ }^{1}$ http://www.1000ev.hu/index.php?a=3\&param=5799 (A letöltés ideje: 2014. december 1.).
} 
szabálya az élet konkrét valóságával, valamint egy laikus embert nem az fogja foglalkoztatni, hogy a bíró melyik szakasz, és milyen elvek alapján szabta ki a büntetést, hanem az, hogy a bíró az adott ügyben mennyit is szabott ki. ${ }^{2}$ A büntetés az elkövetett büncselekmény jogi megtorlása, a bünelkövető felelösségre vonása; általános célja pedig a jövőben várható hasonló tettektől a társadalom, illetve a büntetéssel sújtottak visszatartása. ${ }^{3}$

A megjelölt időszakban a Csemegi-kódexben a relatíve határozott büntetési tételek voltak jellemzők, ${ }^{4}$ mely keretében a törvényhozó megállapította az alsó és felső határát, de ezen belül a bíró feladata volt az eset összes körülményeire tekintettel megállapítani a büntetés mértékét. A büntetés kimérésének általános szabálya, hogy törvényben elöírt határok között figyelembe kell venni minden olyan körülményt, mely a büntetést súlyosbítja, vagy enyhíti. ${ }^{5}$

A büntetést tehát összhangba kellett hozni a büncselekmény alapvető ismérveit alkotó jelenségeknek az adott esetben megállapított fokával. ${ }^{6}$ Ha sem enyhítő, sem súlyosbító körülmény nem forgott fenn, vagy a kettö kiegyenlítette egymást, akkor a bírónak a büntetési tétel középmértékét kellett kiszabnia, amit úgy állapított meg, hogy a büntetési tétel minimumához hozzá kellett adni a minimum és maximum között különbözet felét. ${ }^{7}$ Ha azonban az enyhítő körülmények voltak túlsúlyban, akkor a minimumhoz, ha pedig a súlyosbító körülmények, akkor a maximumhoz közelítő büntetést kellett kiszabnia. A bírónak tehát itt önálló mérlegelési jogköre van, amelynek nagy szerepe van abban, hogy az egyéniesítés törvényes keretek között juthat érvényre. A helyes büntetés kimérése érdekében az eset összes körülményét ismernünk kell, a cél az, hogy a büntetés álljon arányban a büncselekmény súlyával, amit pedig a felmerülő körülmények lényegesen befolyásolnak. ${ }^{8}$

E körülményeknek, a fentebb kifejtettek fényében nagy szerepük van a bünösség fokának megállapításában. ${ }^{9}$ Fontos ugyanis, hogy mindig az egyéni bünösség nagyságához képest szabjuk ki. Ezt pedig csak az enyhítő és súlyosító körülmények megfelelő mérlegelésével tudjuk elérni. E körülményeket csoportosíthatjuk a szerint, hogy tárgyi, vagy alanyi körülményröl van-e szó. Így a súlyosító körülmények közül például a büntetett előélet, a bosszú, a nyereségvágy, a müveltség nagyobb volta, kegyetlenség stb. alanyilag; míg az elkövetés eröszakossága, a nagyobb kár tárgyilag súlyosítja a büntetést. De ugyanígy az enyhítő körülmények közül az indítóok

${ }^{2}$ DR. MAgYaR ISTVÁn: A büntetés kimérése. Bp., 1910. 1.; A büntetés céljáról lásd bővebben: SIPOS FERENC: A büntetés céljának változásai a magyar büntetö anyagi jogban a Csemegi-kódextöl az 1978.évi IV. törvényig. P. Szabó Béla, Szemesi Sándor (szerk.): Profectus in Litteris 3, Debrecen, 249-256; SIPOS FERENC:Determinizmus-indeterminizmuspredestinatio. Jogelméleti Szemle, 2011. 2. sz. 1.

${ }^{3}$ FINKEY FERENC: A magyar büntetöjog tankönyve. Bp., 1905. 39.

${ }^{4}$ FINKEY FERENC: i. m., 462.

${ }^{5}$ VÁMBÉRY RUSZTEM: A büntetőjog. Bp., 1913. 148.

${ }^{6}$ SCHULTHEISZ EMIL: A büntetés kiszabása. Bp., 1953. 5.

${ }^{7} 49$. számú Kúriai döntvény (1885. november 26.)

${ }^{8}$ HeIl FAUSZTIN: A büntetés kimérése. Jogtudományi Közlöny, 1906. 41. évf. 12. sz. 97.

${ }^{9}$ VÁMBÉRY RUSZTEM: i. m., 148. 
menthető volta, büntetlen előélet, megbánás alanyilag, míg a kár csekélysége, az elkövetés szelídebb természete tárgyilag enyhíti a büntetést. A Csemegi-kódex egyébként nem tartalmaz felsorolást e körülményekről, még fogalom meghatározást sem ad, csak utasítást a fennforgó körülmények figyelembevételére. ${ }^{10}$ Az 1843-as büntetőjavaslat azonban tételesen felsorolta az enyhítő és súlyosbító körülményeket. ${ }^{11}$ Ugyancsak az 1870. évi osztrák büntetőjavaslat, a német és a svájci javaslat-tervezetek is. ${ }^{12}$ A későbbi büntetőtörvénykönyvekben már nem találunk rá példát, ugyanis a gyakorlatban a sokrétü élethelyzetekből adódóan mindig felmerülhetnek eltérő körülmények, így lehetetlen kimerítő jelleggel számba venni öket. ${ }^{13}$

„Enyhítö körülménynek minösülnek az olyan körülmények, melyek a beszámítási képességet teljes mértékben nem zárják ki, de az öntudat vagy az akarat korlátozásánál, vagy a cselekmény minöségénél fogva a bünösséget kisebbítik." ${ }^{14}$

Főszabály szerint a bírónak a büntetési tétel minimuma és maximuma között kell kiszabnia a büntetést. Azonban a jogrend lehetővé tette a büntetési tétel leszállítását, melyről már az általános részben is intézkedik; és négy általános leszállító okot határoz meg: rendkívüli enyhítő körülményeket, a serdülő kort, a kísérletet és a bünsegélyt. Ezen kívül nem teljesen leszállításnak, inkább átváltásnak minősül az, mikor a 93.§-ban lehetővé teszi aggkor és testi gyöngeség esetén a fegyház helyett a börtönbüntetés kiszabását. A rendkívüli enyhítő körülmények révén a törvény lehetővé teszi a nagyszámú és nyomatékos enyhítő körülmény fennforgása esetén a minimumtól való kétszeres leszállást, egyrészt a büntetés nem speciális minimumáig, másrészt pedig korrekcionalizációt, ${ }^{15}$ azaz a büntetési nemben való lépést. $\mathrm{E}$ rendelkezéssel is tovább erősíti az individualizáció megvalósítását, valamint a közvetítő iskola térnyerését a hazai igazságszolgáltatásban. ${ }^{16}$ Ilyen kétszeres leszállást alkalmazott az Ítélőtábla több

${ }^{10} 1878$. évi V. törvénycikk a magyar büntetőtörvénykönyv büntettekröl és vétségekről 89 . $\S$, Magyar Törvénytár 1877-1878. évi törvénycikkek. Szerk.: Márkus Dezső. Bp., 1896. 116.

${ }^{11}$ VARGA NORBERT: Az 1843-as büntetö anyagi javaslat létrehozása és büntetési rendszere. Studia Iurisprudentiae Doctorandorum Miskolciensium. Miskolc, 2004. 373-390., BALOGH JENÖ: Nyomor és büntettek. Bp., 1908. 7.

${ }^{12}$ FAYER LÁSZLÓ: Magyar büntetőjog kézikönyve I. Bp., 1900. 292.; DR. DOLESCHALL ALFRÉD: A svájci, az osztrák és német büntetőjavaslatok. Magyar Jogászegyleti Értekezések, 1910. 8. füzet 410.; DR. MAGYAR ISTVÁN: i. m., 9.; LUEBER, CARL: Strafgezetsbuch für das Deutsche Reich. Erlangen, 1876. 16-23.; OPENHOFF, FRIEDRICH: Das Strafgesetsbuch für das Deutsche Reich. Berlin, 1901. 138-244.

${ }^{13}$ SCHULTHEISZ EMIL: i. m., 3.

${ }^{14}$ PAUler TIVADAR: Büntetőjogtan. Bp., 1869-1870. 246.

${ }^{15} \mathrm{~A}$ francia jogban a korrekcionalizáció intézménye más jelentéstartalommal bír, itt ugyanis ennek keretében az eljárás gyorsítása végett, azért, hogy ne legyen az esküdtszéki tárgyalás szükséges; az ügyész eltekinthet bizonyos súlyosító körülményektől, vagy a tényállás egyes elemeitől, amelyek figyelembe vételével a vétség büntetté minősülne. VÁMBÉRY RUSZTEM: i. m., 150-153., SZÉKELY FERENC: A magyar büntetötörvénykönyv büntetési és börtönrendszerének jelenlegi végrehajtása és ennek eddigi eredményei. Magyar Jogászegyleti Értekezések. V. kötet, 3. füzet, 10.

${ }^{16}$ IRK ALBERT: A büntetőjog átalakulása. Bp., 1915. 121. 
ügyében is. ${ }^{17}$

A büntetési tétel minimumának átlépésével ellentétben azonban, bármennyi súlyosító körülmény is forog fenn, föszabály szerint a speciális maximumot nem haladja meg a bíró a büntetéskiszabás során. Ez alól kivételt jelent a halmazati összbüntetés esete, de még így sem haladhatja meg a törvény által elöírt generális maximumot, azaz a 15 évet.

Súlyosító körülmény minden olyan körülmény: „,mely a felmerült esetben vagy alanyilag, vagy tárgyilag nagyobbnak tünteti fel a tettes bünösségét, sulyosabbnak a jogsérelmet, közvetlenebbnek, s nagyobbnak a veszélyt, mely a cselekményböl egyesekre, a társadalomra vagy az államra hárulhatott."18

A súlyosító körülmények az adott időszakban sokkal kisebb számmal, és jelentőséggel fordultak elö, mint az enyhítő körülmények, a megvizsgált időszakban abban a néhány esetben ahol nem került sor a büntető törvénykönyv 92. §-nak alkalmazására, ott sem került sor középmértéken felüli büntetésre.

Persze ez nem jelentette azt, hogy a bíróságok teljesen figyelmen kívül hagyták volna, a leggyakrabban előforduló súlyosító körülmények voltak: a büntetett előéletet, a kár nagy mértéke, az, hogy a cselekmény a közérdekes súlyosan sértette, ${ }^{19}$ a nagy kitartás, az üzletszerüség, a magas müveltségi fok, a halmazat. Ezek közül a büntetett előélet okozott eltérést a bíróságok megítélésében. Mégpedig abból az alapelvből kifolyóan, hogy amit egyszer már minősítő körülményként értékel a jogalkotó, azt már nem lehet súlyosító körülményként is figyelembe venni. Az enyhítő és súlyosbító körülmények megítélésére a gyakorlat különböző elveket alakított ki:

- Súlyosbító körülmény hiánya még önmagában nem enyhítő körülmény, és úgyszintén fordítva sem ${ }^{20}$

- Kétszeres értékelés tilalma (ne bis in idem), vagyis ha a jogalkotó bizonyos körülményt már minősítő, vagy privilegizáló esetként értékelt, akkor ugyanazt a körülményt már nem lehet enyhítőnek, vagy súlyosbítónak figyelembe venni. Ez alól kivétel, a fokozható tényálláselem, ami a konkrét esetben jelentősen meghaladja a minősítéshez szükséges mértéket. ${ }^{21}$

Ilyen pl. az a körülmény, amikor egy eltulajdonított dolog értéke a minősítéshez szükséges mértéket jelentősen meghaladja. Így járt el a bíróság Z. Sándor ügyében: ${ }^{22}$

\footnotetext{
${ }^{17}$ Magyar Nemzeti Levéltár Hajdú-Bihar Megyei Levéltár (továbbiakban: MNL HBML) VII. 2/b. 52. d. BII. 1729/8/1923., 42. d. B. 1494/28/1921., 39. d. BV. 1307/7/1920., 40. d. B. 678/13/1921., 44. doboz BII. 426/49/1922., 45. d. BII. 525/16/1922., 46. d. BI. 1119/53/1922., 50. d. BII. 937/7/1923., 53. d. BI. 1908/7/1923., 59. d. BI. 3059/15/1924.

${ }^{18}$ FINKEY FERENC: i. m., 469.

${ }^{19}$ MNL HBML VII. 2/b. 42. d. B. 1817/18/1921., és még 40. d. B. 334/7/1921., 44. d. BII. 415/18/1922., 49. d. BI. 2741/1922., 60. d. BI. 434/5/1925, 59. d. BII. 4948/18/1924., 56. d. BI. 551/49/1924.

${ }^{20}$ BALOGH JENÖ: i. m., 149.

${ }^{21}$ VÁMBÉRY RUSZTEM: i. m., 149., FAYER LÁSZLÓ: i. m., 348.

${ }^{22}$ MNL HBML VII. 2/b. 38. d. BV. 675/11/1920.
} 
Z. Sándort Hajdúsámsonban R. Jánosné örököseinek tulajdonát tevö, az ö ôrizetére bízott, és így birtokában levö idegen ingó dolgokból 1 métermázsa búzát, 2 métermázsa rozsot, és 6 szekér szénát, így összesen 300 Koronát meghaladó értékben elidegenítve, jogtalanul tulajdonított el.

A törvényszék ebben az ügyben a fennálló nyomatékos és nagyszámú enyhítő körülmények miatt a Btk. 92.§ és a Btk. 20.§ képest sikkasztás vétségévé minősítette, de súlyosító körülményként mérlegelte: hogy az eltulajdonított ingók értéke többszörösen meghaladja a minősítés alapjául szolgáló összeget.

- Egy büncselekmény két vagy több rendelkezés szerinti minősülése súlyosító körülmény. ${ }^{23}$

- Fontos, hogy a bíróság ne a körülmények számát, hanem a súlyát vegye figyelembe, tehát mérlegelje, hogy a büntetési cél elérése érdekében milyen mértékben szükséges a büntetés súlyosbítása, vagy enyhítése.

A kutatásom során arra a megállapításra jutottam, hogy a bírói gyakorlat a büntetéskiszabás tekintetében jelentős eltéréseket mutat a törvényi szabályozáshoz képest az enyhítő és súlyosító körülmények mérlegelésénél, és a büntetőtörvénykönyv 92.§-ának alkalmazásában. Amikor a bíró kiszabja a büntetést, ahhoz, hogy az a célnak megfelelő legyen, figyelemmel kell lennie arra is, hogy a törvényhozó azt a bizonyos jogintézményt milyen céllal is illesztette bele a büntetőkódex rendszerébe. Ha az ilyen történeti értelmezésből indulunk ki, akkor arra juthatunk, hogy nagy valószínűséggel a jogalkotó a 92. §-t, a rendkívüli enyhítés jogát, kivételként illesztette bele a föszabály mellé, hogy a büntetést a különös részben a szakaszonként meghatározott büntetési tétel keretén belül szabja ki. Ha azonban megnézzük ebben az időszakban, a gyakorlatban való előfordulásának számát, joggal mondhatjuk, hogy ebben az esetben a jogvalóság ellentmond a jogrendnek, ugyanis az, ami eredetileg kivételként indult, szinte föszabállyá avanzsálódott. ${ }^{24}$

Az általam vizsgált ügyekben ugyanis a bíróság az 1921 és 1925 között elöforduló vagyon elleni büncselekmények több mint 2/3-nál a Büntetőtörvénykönyv 92. §-át alkalmazhatónak találta. ${ }^{25}$ Az ügyek többségében enyhítő körülményként mérlegelte a büntetlen elöéletet, ${ }^{26}$ a vádlott beismerését,${ }^{27}$ a kár csekélyebb voltát, ${ }^{28}$ a nagycsaládot ${ }^{29}$ és az ügyhöz köthető egyéb körülményeket.

\footnotetext{
${ }^{23}$ SCHULTHEISZ EMIL: i. m., 51-55.

${ }^{24}$ DR. MAGYAR ISTVÁN: i. m., 8.

${ }^{25}$ Vö. MNL HBML VII. 2/b. 59. d. BI. 3061/9/1924., 60. d. BII. 249/16/1925., 61. d. BI. 733/75/1925., 63. d. BIII. 2531/5/1925., 42.d. B. 1564/17/1921., 39. d. BV. 1307/7/1920., 38. d. BV. 576/6/1920.

${ }^{26}$ MNL HBML VII. 2/b. 42. d. B. 1564/17/1921., 38. d. BV. 805/9/1920., 44. d. BII. 151/12/1922., 49. d. BI. 2602/8/1922.

${ }^{27}$ MNL HBML VII. 2/b. 50. d. BI. 764/7/1923., 53. d. BI. 1925/4/1923., 60. d. BII. 266/15/1925, 64. d. BI. 3000/6/1925.

${ }^{28}$ MNL HBML VII. 2/b. 65. d. BII. 3417/4/1925., 38. d. BIV. 590/9/1920., 44. d. BI. 132/7/1922., 50. d. B. 935/25/1923.
} 
E körülmények nagyszámú és nyomatékos fennforgása mellett a vádlottra a cselekménye által kimerített törvényi tényállásban megjelölt büntetés legkisebb tartama is túlságosan szigorú volna, és nem állna arányban az általa elkövetett büncselekménnyel.

Ezért például a Büntető törvénykönyv 92. §-t alkalmazta N. József ügyében: ${ }^{30}$

N. József (28 éves, férfi, festö) sikkasztást követett el, mégpedig úgy, hogy Miskolcon, mint a Magyarországi vegyészeti munkások miskolci fiókjának pénztárnoka a miskolci fiók részére segélyképpen felvett magas sorszámú, 1000 Korona értékü, és a 3975/1919 M.E. számú rendelet értelmében a rendelet felhívásától számított 48 óra alatt beszolgáltatandó fehér pénzzel jogtalan eltulajdonítási szándékkal, mint sajátjával rendelkezett.

Ezen cselekményért a Btk. 358. § -a (2) bekezdése alapján a 92. § alkalmazásával három hónapi fogházra, mint főbüntetésre, és 1 évi hivatalvesztésre, és politikai jogai gyakorlásának felfüggesztésére ítélték. Súlyosító körülmény hiányában enyhítő körülményként értékelték a vádlott büntetlen elöéletét, beismerését, a cselekmény idejében a társadalomra, s különösen a gyengébb erkölcsi ellenállással bíró vádlottra káros mérvben ható téveszmék befolyását. Az Ítélőtábla az első fok által felsorolt enyhítő körülményeket elfogadta, és a kiszabott büntetést az elkövetett büncselekménnyel helyes arányban állónak találta.

Így azt is észrevehetjük, hogy az eredetileg kiindulópontként meghatározott középmértékre a gyakorlatban szinte nem találunk példát. Persze ez adódhat abból is, hogy csak elméletileg létezhetnek olyan esetek, ahol se enyhítő, se súlyosító körülmény, vagy a kettő egymást kiegyenlítő arányban fordulna elő. De észrevehetünk egy olyan tendenciát, hogy ez a mérték már nem a középmértékkel esik egybe, mert a súlyosító körülmények túlnyomó fennforgás esetén is, nem a középmértéktől felfelé súlyosítják a büntetést, hanem szinte magának a középmértékhez közeli büntetési tétel kiszabásához is súlyosító körülménynek kell fennforognia. ${ }^{31}$

Ilyen visszásságot figyelhetünk meg például S. Kálmán ügyében, ahol bár a súlyosító körülmények voltak túlsúlyban, mégis jóval a középmértéken alul szabták ki a büntetést:

S. Kálmánt a Debreceni Királyi Törvényszék bünösnek találta 1 rendbeli sikkasztás büntettében, és 2 rendbeli sikkasztás vétségében, amelyet úgy követett el, hogy D. Miklóstól átvett csináltatás végett 9000 Koronát meghaladó értékü aranyórát, majd K. Jánostól hasonló célból 2000 Koronán aluli ezüstórát, és F. Károlytól is átvett egy 2000 Koronán alul maradó értékü nöi órát, melyeket, mint a

\footnotetext{
${ }^{29}$ MNL HBML VII. 2/b. 42. d. B. 1494/28/ 1921., 42. d. 1531/6/1921., 39. d. BV. 1307/7/1920., 41. d. B. 1365/37/1921., 45. d. BI. 469/19/1922.

${ }^{30}$ MNL HBML VII. 2/b. 45. d. BI. 590/14/1922.

${ }^{31}$ KÁRMÁN ELEMÉR: Az 1902. évi bűnügyi statisztika szabályai a büntetés kiszabása szempontjából. Jogtudományi Közlöny, 1904. 39. évf. 34. sz. 273.
} 
birtokába jutott idegen ingó dolgokat jogtalanul eltulajdonított. Ezért a bíróság a Btk. 98. § -ban meghatározott összbüntetésre figyelemmel 1 évi börtönre, mint föbüntetésre, és 3 évi hivatalvesztésre, valamint politikai jogai ugyanilyen tartamú felfüggesztésre itélte, mely kiszabásánál súlyositó körülményül vette figyelembe, hogy a vádlott már büntetve volt, illetve a kettönél több halmazatot. ${ }^{32}$

A Büntetö törvénykönyvben foglaltak szerint, a sikkasztás vétségére 1 évig terjedő fogházzal, míg a büntette 5 évig terjedő börtönbüntetéssel büntethető. Speciális minimumot itt a törvényhozó nem határoz meg, hanem arra az Általános részben foglalt generális minimum az irányadó. Így a bíróságnak a sikkasztás bűntette esetén fél év és 5 év között kell megállapítani a középmértéket, ami jelen esetben 2 év 9 hónap lenne. Már csak ettől az értéktől is szembetünően alul marad a bíróság által kiszabott büntetés, nem beszélve arról, hogy összbüntetés esetén mindez két évvel felemelhetö is lenne. ${ }^{33}$

Annak, hogy a törvényi szabályozás és a gyakorlat között ilyen nagy eltérés mutatkozott, a háború hatásai egyértelmüen jelentős szereppel bírtak, így a következőekben arra térnék ki, hogy ezen hatások miképp is jelentkeztek.

Kétségtelen, hogy a háborút követő válságos években a területvesztés, jóvátételi kötelezettség, a megrokkant és eltorzult gazdaság, az elszegényedés súlyosan megrendítette az állampolgárokat testileg-lelkileg. Ezek a hatások befolyással bírtak mind az elkövetőkre, mind a bírókra. Ezekből fakadóan a folytonosan növő munkanélküliség miatt egyre több ember került kilátástalan helyzetbe, aminek az lett a következménye: - amit a statisztikai adatókból megállapíthatunk - hogy a kriminalitás nagymértékben megnövekedett, ${ }^{34}$ és kialakult egy sajátos kategória: az úgynevezett megélhetési bünözés. Nyilvánvaló, hogy a háború e hatása nagyrészt a vagyoni elleni büncselekmények kapcsán vezetett jelentős növekedéshez, amelyet jól illusztrálnak a korszakból származó statisztikai adatok. Míg egy háború előtti bünügyi statisztika 30781 vagyon elleni büncselekményt jelez, ${ }^{35}$ azaz az összes bủnelkövetés körülbelül 31\%-át, addig egy 1921 és 1925 közötti mutató már jelentősen növekvő tendenciát mutat. A nevezett időszakban csak lopás 68317 történt. ${ }^{36}$ Mindezek közül a legkiugróbb számot az 1923-as év kriminalitása mutatja, melyet jól alátámaszt az, hogy a Debreceni Ítélőtáblán is ebben az évben az ezt megelőzőekhez képest (1920-ban 29, 1921-ben 40, 1922-ben 75) jóval többet, azaz az 1923-as évben a bíróság 103 vagyon elleni büncselekményt bírált el. Ez az emelkedő tendencia, azzal hozható összefüggésbe, hogy a háborúban megrokkant gazdaságunk következtében talán ekkor tetőzött a munkanélküliség, általában pedig

\footnotetext{
${ }^{32}$ MNL HBML VII. 2/b. 50. d. BI. 764/7/1923.

${ }^{33} 1878$. évi V. törvénycikk a magyar büntetőtörvénykönyv büntettekről és vétségekről $98 . \S$, 358.§, Magyar Törvénytár 1877-1878. évi törvénycikkek. Szerk.: Márkus Dezső. Bp., 1896. 117., 155.

${ }^{34}$ AURER GYÖRGY: Háború és kriminalisztika. Jogtudományi Közlöny, 1917. 52. évf. 7. sz. 66.

${ }^{35}$ Bünügyi statisztika (1904). Jogtudományi Közlöny, 1906. 41. évf. 7. sz. 54.

${ }^{36}$ HACKER ERVIN: Kriminalitásunk az 1921-1927. években. Miskolc, 1929. 6.
} 
a válságoknak - akárcsak egy rossz termést hozó évről is legyen szó - jelentős kriminalitást emelő hatása van, ${ }^{37}$ hiszen a gyengébb jellemeket a bünözés, mint létfenntartási mód felé terelheti. E szerint állandó párhuzam fedezhető föl a kriminalitás és a gazdasági feltételek alakulása között; minél állandóbbak a gazdasági feltételek, annál alacsonyabbra tehető a kriminalitás száma. ${ }^{38}$

Mindezekből következik, hogy a kriminalitásra hatást gyakorló tényezők nagyszámúak, vannak, amelyek közvetlenül és vannak, amelyek csak közvetve gyakorolnak hatást. Így a világháborúnak is volt még egy nagy befolyással bíró közvetett hatása a büntetéskiszabásra, ez pedig a pénz elértéktelenedése. Ez ezért fontos a büntetéskiszabás szempontjából, mert a vagyon elleni büncselekményeknél az érték a meghatározó abból a szempontból, hogy a büntetendő cselekmény büntettnek, vagy vétségnek minősül, illetve a kisebb vagy nagyobb érték enyhítő vagy súlyosító körülmény lehet; ha jelentősen alulmarad, vagy meghaladja a minősítés alapjául szolgáló értékhatárt. Eredetileg a Csemegi-kódex által meghatározott lopás vétségének értékhatára 100 Korona volt, majd az első Büntetőnovella megemelte 200 Koronára, azonban ezt már a bíróság akkor is túl szigorúnak tartotta és például a lopások 1/3 részében alkalmazta a 92. §-t. Illetve 4000 Koronában határozta meg a büntett értékhatárát, mert jellemzően, aki ilyen értékben lopott, az olyan vakmerőséget feltételezett, amely az enyhítő körülmények teljes hiányára vallanak. ${ }^{39}$ Később a háború hatására bekövetkező elértéktelenedés következtében ezek az értékhatárok tarthatatlanok voltak, így az 1921: XXVIII. törvény, a II. Büntetőnovella 2000 illetve 40000 Koronára emelte. A gyakorlat azonban a további árdrágulások miatt ezt a 2000 Koronát is alkalmatlannak találta. Az egész értékemelkedés azzal járt, hogy a járásbíróságok hatásköre és tevékenysége a minimumra csökkent, míg a törvényszékek a csekély vagyoni jelentőségü bünügyek tömkelegével küzdött. A törvényszékek által elbírált ilyen ügyek folytán a széles körben igénybe vehető perorvoslati jogoknak köszönhetően a felsőfokú bíróságokhoz is rengeteg ügy került. Ezt tetőzte, hogy a tényleges helyzeteknek meg nem felelő értékhatár kirívó aránytalanságot okozott az elkövetett cselekmény és a rá kiszabható büntetés között. ${ }^{40}$ Például aki egy libát lopott, az nem kihágást követett el, hanem vétséget, mert 6 Koronáról 8000K-ra emelkedett az ára. A bírói gyakorlatnak ezért elsődleges feladata lett, hogy a törvény változatlan büntetési tételeit a változó társadalmi szükségleteinek megfelelően kell alkalmaznia. ${ }^{41}$ Mert a jog nem akkor tölti be a feladatát, ha mereven ragaszkodik a meglévő szabályozási rendszerhez, hanem akkor, ha rugalmasan követni tudja a változó életviszonyokat legyen szó akár ilyen kirívó esetekről, melyeket háború idéz elő, vagy éppen csak a fejlődő világgal kelljen lépést tartania. ${ }^{42}$ Olchváry Zoltán

\footnotetext{
${ }^{37}$ Bud JÁNOS: Bünügyi statisztika. Jogtudományi Közlöny, 1906. 41. évf. 9. sz. 73.

${ }^{38}$ VÁMBÉRY RUSZTEM: i. m., 12.

${ }^{39}$ ALFÖLDI DÁVID: Értékhatár és büntetés. Jogtudományi Közlöny, 1923. 58. évf. 8. sz. 61.

${ }^{40}$ AURER GYÖRGY: Büntetőjogi reformkérdések. Jogtudományi Közlöny, 1923. 58. évf. 8. sz. 58.

${ }^{41}$ HeIl FAUSZTin: A büntetés kimérése. Jogtudományi Közlöny, 1906. 41. évf. 12. sz. 97.

${ }^{42}$ ANGYAL PÁL: A háború hatása büntetöjogunkra. Magyar Jogászegyleti Értekezések. Bp., 1916. 20.
} 
kúriai bírót idézve: „Annak, hogy az igazságügyi törvények a gyakorlatban nem vállnak be, két fö oka lehet. Az egyik az, hogy a bíróságok helytelenül alkalmazzák a törvényeket, és annak intencióit félreértve helytelen gyakorlatot követnek, a másik ok, hogy a törvények nincsenek összhangban az életviszonyokkal, mert a törvények elökészitése és meghozatala az életviszonyok alapos ismerete nélkül történnek." ${ }^{43}$

Jelen esetben a bíróságok ezt úgy tudták kiküszöbölni, hogy szinte minden ilyen aránytalan esetnél a 92. § alkalmazásához nyúltak. Egyébként maga az egykori igazságügyi miniszter Vázsonyi Vilmos rendeletben hívta fel az alkalmazására a bírók figyelmét minden olyan esetben, amikor a normális értékelés mellett az értékhatáron alapuló súlyosabb minősítés nem lett volna alkalmazható. Ugyanis célszerütlen lenne az elkövetöt tettének oly körülményei miatt is büntetni, melyet elöre nem látott, mert a büntetés, mint lélektani ellenmotívum teljesen hatástalan, ha az eredmény, melyen alapszik a tettes akarati megnyilvánulásától függetlenül jött létre. ${ }^{44}$ Mindez tükröződik az általam vizsgált esetekben is, hiszen a legtöbbnél a bíróság alkalmazta a 92. §-t, külön enyhítö körülményként emelte ki, hogy csak a háborús értékemelkedés következtében minősül a büncselekmény vétséggé, vagy büntetté. Így járt el például Sz. Kálmán ügyében: ${ }^{45}$

Sz. Kálmán Újfehértó község kárára, a községi hullaház területéröl, nyílt helyröl 200 Korona értéket meghaladó ingóságot; két karosszéket és egy asztalt a sértett birtokából beleegyezése nélkül oly célból vett el, hogy azt jogtalanul eltulajdonítsa.

Ebben az ügyben az elsőfokú bíróság a Nyíregyházi Törvényszék súlyosító körülményként mérlegelte a halmazatot, míg ezzel szemben enyhítő körülményként a vádlott beismerését, büntetlen eloéletét, sokévi harctéri szolgálatát, illetve azt hogy a kár megtérült. Ezekre figyelemmel lopás büntette miatt ítélték a Btk. 92. §-nak alkalmazásával a törvényben meghatározott fegyház helyett 7 hónapi börtönbüntetésre és 3 évi hivatalvesztésre, valamint politikai jogai felfüggesztésére. A büntetés súlyossága miatt bejelentett fellebbezés okán a Debreceni Ítélőtábla ugyan helybenhagyta a 92 . $§$ alapján kiszabott büntetést, de módosított a figyelembe veendő enyhítő körülményeken, mellőzte a halmazatot, mint súlyosító körülményt, illetve a beismerését és a kár megtérítését, mint enyhítő körülményként való mérlegelését. Habár a törvényszék által felsorolt enyhítő körülményeken kívül annak találta még azt, hogy a vádlott ittas volt, illetve hogy az eltulajdonított ingók értéke a háborús viszonyok következtében emelkedtek meg aránytalanul nagyobb összegre, de súlyosítóként értékelte, hogy a lopást éjjel követte el.

A háború hatásai jól tükröződnek a gyakorlatban, ugyanis a büntetés kiszabásánál a háborúval kapcsolatos befolyásoló körülményeket is értékelték. Például azt, hogy a

${ }^{43}$ GÁL JENŐ: Büntetőjogunk fejlődése és a háború. Magyar Jogászegyleti Értekezések. Bp., 1916. 5.

${ }^{44}$ VÁMBÉRY RUSZTEM: A büntetőjogi értékhatár felemelése. Jogtudományi Közlöny, 1917. 52. évf. 42. sz. 368.

${ }^{45}$ MNL HBML VII. 2/b. 38. d. BV. 657/02/1920., de erre találhatunk példát többek között: MNL HBML VII. 2/b. 40. d. B. 334/7/1921., 41. d. B. 895/12/1921., 44. d. BI. 388/10/1922. 
vádlott hosszú időn át teljesített katonai szolgálatot, vagy, hogy ez alatt az idő alatt maradandó sérüléseket szerzett, enyhítő körülménynek számították be. Így jártak el például P. Pál ügyében: ${ }^{46}$

P. Pált a Miskolci Királyi Törvényszék bünösnek találta, a Btk. 92. §-ra figyelemmel, a Btk. 20. \$-nak alkalmazásával sikkasztás vétségében, amelyet úgy követett el, hogy D. J. által a neki kézbesités végett átadott 5000 Korona készpénzt, mint birtokában lévö rá nézve idegen ingó dolgot jogtalanul eltulajdonította, az által, hogy azt a sértett elött leszállítottnak állította.

A törvényszék ezért 8 napi fogházbüntetésre ítélte, a büntetéskiszabásnál pedig figyelembe vette, mint enyhítő körülményt a vádlott büntetlen elöéletét, harctéren szerzett érdemeit, több ízbeli sebesülését, kitüntetéseit, illetve, hogy a sértett kártérítést nem követelt.

Persze azt is meg kell említenünk, hogy a jogtudomány erre sem reagált egyöntetüen, ugyanis voltak, akik szerint ezeket a háborús szolgálattal kapcsolatos enyhítő körülményeket nem kellene a vádlott javára értékelni, ugyanis azok nincsenek befolyással közvetlenül a vádlott bünösségére. ${ }^{47}$ Szemben azzal, hogy például a nagyszámú család azért jöhet szóba, mert mint a családja megélhetése iránti félelem motívumként merülhet föl. A Debreceni Ítélőtábla is az általam vizsgált ügyek közül, egyetlen egyben azt mondta ki, hogy mellőzi a királyi törvényszék által elfogadott harctéri szolgálatot, mint enyhítő körülményt, arra hivatkozva, hogy az polgári kötelezettség. ${ }^{48}$

A háború másik közvetett hatásaként tudható be, a társadalmi kapillaritás, ami szintén jelentős hatással volt az enyhítő és súlyosító körülmények megítélésére. „, $A$ társadalmi kapillaritás más társadalmi rétegekbe való behatolás, beszivárgás." 49 Önmagában ez a folyamat nem mindig jelent rosszat, hiszen az alacsonyabb társadalmi rétegekből a magasabban állók rétegébe való behatolás alapvetően egy ösztönző fejlődési folyamat, ha feltételezzük, hogy olyanok kerülnek feljebb, akiknek meg is vannak hozzá a kellő képességei ${ }^{50}$ De a háború következtében nem csak hazánkban, hanem más országokban is jellegzetesen a társadalmi kapillaritás negatív hatása érvényesült. Ugyanis a hadba vonuló férfiak - a családfenntartó szerepét betöltő apák - helyét mind a családfenntartásban, mind a munka terén az itthon maradó nők és sokszor a fiatalkorú fiúk vették át. Természetesen ez az esetek többségében azt eredményezte, hogy a megkívánt képességekkel nem rendelkező társadalmi elemek olyan közegbe kerültek be, amelyben szokatlanul nagy

\footnotetext{
${ }^{46}$ MNL HBML VII. 2/b. 49. d. BII. 2/6/1923., 49. d. BII. 5/20/1923., 52. d. BII. 1729/8/1923.

${ }^{47}$ DEGRÉ MiKLÓs: Az 1928. év büntető igazságszolgáltatása. Jogállam. Jog és Államtudományi Szemle XXVIII. évf. 101.

${ }^{48}$ MNL HBML VII. 2/b. 63. d. BII. 2406/8/1925.

${ }^{49}$ HACKER ERVIN: Társadalmi kapillaritás és kriminalitás. Büntetőjogi dolgozatok Finkey Ferenc irodalmi munkássága négy évtizedes évfordulójának emlékére. Pécs, 1936. 98.

${ }^{50}$ ANGYAL PÁL: A fiatalkorúak bírósága a háború alatt és háború után. Jogtudományi Közlöny, 1917. 52. évf. 17. sz. 154.
} 
munkabérhez jutnak, amely fölött ők maguk rendelkezhettek. Ez pedig gyakran ahhoz vezetett, hogy a kísértéseknek ellent nem állva káros szenvedélyeik, vágyaik kielégítése végett a bün útjára léptek. Tarde mondta: „nem a szegénység, vagy a nyomor a fó ok, hanem a gazdasági helyzettel való elégedetlenség, az igények fokozódása, a fényüzés, a vagyonosodás vágya, a munkanélküli kényelmes megélésre való törekvés." ${ }^{51}$ Egyértelmü, hogy míg a legtöbb nő otthon a háztartást vezette, nem volt lehetősége olyan büncselekmények elkövetésére, melyhez annak révén jutottak, hogy például a férfiak helyét átvéve vállalatoknál, hivataloknál megnyílt a lehetőségük a csalás, sikkasztás elkövetésére. ${ }^{52}$ Így míg a világháború előtti években a női kriminalitás száma az összeshez viszonyítva körülbelül 15\%-ra volt tehető, addig e körülményekből fakadóan a háború alatt és utáni években átlagosan 25-30 \%-ra tehető ez az arány, de volt olyan év (1917), amikor elérte a 47 \%-ot is. A statisztikai adatok alapján hasonló emelkedő tendenciát figyelhetünk meg a fiatalkorúak körében is. ${ }^{53}$

Mindezen számba vett körülmények és tényezők arra vezettek, hogy jelentősen megnőtt az úgynevezett alkalmi bünözők száma. Vámbéry Rusztem szavaival élve az alkalmi bünözőket ,az ellenálló képesség és az elörelátásnak csekélyebb foka jellemez, úgy, hogy a külsö körülmények hatása könnyen készteti büntett elkövetésére." ${ }^{54} \mathrm{Ez}$ pedig a gyakorlatban ott érhető tetten, hogy a vizsgált esetekben a büntetlen előélet, mint enyhítő körülmény jelentősen nagy számban forgott fenn. ${ }^{55}$

A vizsgált esetekből továbbá jól kitünik, hogy a bírák előszeretettel értékeltek a vádlottak javára a saját szubjektív helyzetükkel kapcsolatos enyhítő körülményeket. Olyanokat, mint például a népes család sok eltartottal, a nyomorgó életkörülményeket, a nyomasztó anyagi helyzetet, vagy előfordult olyan is, amikor azt értékelték enyhítő körülménynek, hogy a vádlott élelmiszercikket lopott, amely büncselekmény nélkül egyébként a családjának nem tudott volna élelmiszert biztosítani. ${ }^{56}$ De a XVI. 11. számú Kúriai döntvény is kimondta, hogy a vádlott családjának számos tagból álló voltát és azt, hogy a „fővárosban uralkodó drágaság mellett bizonyos fizetési összeg az életszükségletek fedezésére elégséges nem lévén" enyhítő körülményként beszámítható. ${ }^{57}$ Tehát az, hogy valaki vagyontalan, és kevés befolyó havi jövedelemmel rendelkezik, az önmagában enyhítö körülményt jelent. Ez pedig alátámasztja azt, hogy a bírák ebben az időszakban, a fennálló társadalmi körülményekre tekintettel, igenis szinte külön büncselekményi kategóriaként értékelték a megélhetési bünözést, így e szociológiai okok jelentős befolyással bírtak a büntetés kiszabására.

\footnotetext{
${ }^{51}$ FINKEY FERENC: i. m., 137.

${ }^{52}$ A csalásról lásd bővebben MADAI SÁNDOR: A csalás tényállása a Csemegi-kódex és az I. Büntető novella tükrében. Jogtörténeti Szemle, 2008. 4. szám. 21-28.

${ }^{53}$ HACKER ERVIN: i. m., 99-101., FINKEY FERENC: A magyar anyagi büntetőjog jelen állapota, Bp., 1923. 20.

${ }^{54}$ VÁMBÉRY RUSZTEM: i. m., 36.

${ }^{55}$ Vö. MNL HBML VII. 2/b. 48. d. BI. 2253/10/1922., 49. d. BI. 2741/1922., 58. d. BI. 2586/6/1924., 64. d. BI. 2942/5/1925., 61. d. BII. 923/5/1925.

${ }^{56}$ MNL HBML VII. 2/b. 45. d. BI. 824/6/1922., 59. d. BI. 3039/10/1924., 59. d. BI. 35/34/1925., 50. d. BI. 936/4/1923.

${ }^{57}$ FAYER LÁSZLÓ: i. m., 350.
} 
Összességében megállapítható tehát, hogy a büntetéskiszabás törvényi szabályozása és annak a gyakorlatban való érvényesülése között jelentős eltérések mutatkoztak, melyek nagyrészt a háború hatásainak tudhatóak be. Ez legfőképpen abban jelent meg, hogy a 92. § a bíróknak szinte korlátlan hatalmat adott a büntetés mértékének megállapításában. ${ }^{58}$ Így az elbírált esetek többségében a bíróságok a 92.§ alkalmazásával a főszabályként megállapított középmértéktől eltérve, azt meg sem közelítő rendkívül alacsony büntetést szabtak ki. Az ilyen eseteknél azt hiszem, a bíróság akaratlanul is túlzott szociális érzékenységet mutatott. Ugyanis az értékeltolódások miatt eléjük került rengeteg csekélyebb jelentőségü ügyben annak betudhatóan, hogy a háborút követő borzalmak után senkit nem akartak kegyetlen, túl súlyos büntetésekkel sújtani, az esetek többségében próbáltak akarva-akaratlanul minél több enyhítő körülményt felsorakoztatni, ezért olyanok is figyelembe jöhettek, mint a háborús katonai szolgálat, illetve az ez által okozott testi-lelki megrendülés, aminek valójában az egyéni bünösséghez nem sok köze volt. ${ }^{59} \mathrm{Az}$ ilyen esetekben a bíróság csak az egyéni szubjektív bünösségre volt figyelemmel, de a társadalmi objektív érdekeket pedig teljesen figyelmen kívül hagyta. Ez pedig a másik oldalról ahhoz vezethetett, hogy akár az elkövetö, akár a társadalom más tagjai, akik egy kicsit is gyengébb jellemüek voltak, a nélkülözés megszüntetése végett gyakrabban fordultak a bünelkövetés útjára, ugyanis tudva levő volt, hogy nem számíthatnak túl nagy büntetésre.

A másik oldalról azonban, a bírák számos esetben az enyhítő körülmények felhasználásával próbáltak alkalmazkodni a kor sajátos fennálló viszonyaihoz, mely által olyan körülmények is jelentőséggel bírhattak a büntetéskiszabás során, amelyet a klasszikus iskola tanaira épülő Csemegi-kódex nem tartalmazott. Majd a közvetítő iskola tanai és a humanizmus térnyerése következtében a társadalom által egyre elfogadottabb, és kívánatosnak tartott követelmények fogalmazódtak meg a fennálló rendszerrel szemben, mint az egyénesítés, igazságosság, arányosság, melyek mindenképpen magukkal vonták a büntetőtörvénykönyvük reformjának igényét, amely azonban még jó pár évig váratott magára. De le kell szögeznünk, hogy a fennálló társadalmi viszonyokhoz és követelményekhez a hazai bírói gyakorlat még ha a kívánatos törvényi szabályozás hiányában sokszor következetlenül, és nem egyöntetüen is - nagyszerüen tudott alkalmazkodni és az ítéletekben megjelentek a modern kor büntetőjogának elemei. A kor nagy szellemiségei, mint Angyal Pál, Finkey Ferenc, Fayer László vagy Vámbéry Rusztem müveiken keresztül ugyan keresték a választ megoldásra váró feladatokra, de törvényi szinten való kodifikálásukra csak később kerülhetett sor.

\footnotetext{
${ }^{58}$ EÖRDÖGH ANDRÁS: A büntetlen előélet, mint enyhítő körülmény. Jogtudományi Közlöny, 1895. 30. évf. 15. sz. 118.

${ }^{59}$ DEGRÉ MiKLÓs: Az 1928. év büntető igazságszolgáltatása. Jogállam. Jog és Államtudományi Szemle, 1929. 28. évf. 3. sz. 101.
} 